\title{
CHROMOSOME NUMBERS OF THE EAST AFRICAN GIANT SENECIOS AND GIANT LOBELIAS AND THEIR EVOLUTIONARY SIGNIFICANCE'
}

\author{
ERIC B. KNOX ${ }^{2}$ AND ROBERT R. KOWAL \\ Herbarium and Department of Biology, University of Michigan, Ann Arbor, Michigan 48109-1048; and \\ Department of Botany, University of Wisconsin, Madison, Wisconsin 53706-1981
}

\begin{abstract}
The gametophytic chromosome number for the giant senecios (Asteraceae, Senecioneae, Dendrosenecio) is $n=50$, and for the giant lobelias (Lobeliaceae, Lobelia subgenus Tupa section Rhynchopetalum) it is $n=14$. Previous sporophytic counts are generally verified, but earlier reports for the giant senecios of $2 n=20$ and ca. 80 , the bases for claims of intraspecific polyploidy, are unsubstantiated. The 14 new counts for the giant senecios and the ten new counts for the giant lobelias are the first gametophytic records for these plants and include the first reports for six and four taxa, respectively, for the two groups. Only five of the 11 species of giant senecio and three of the 21 species of giant lobelia from eastern Africa remain uncounted. Although both groups are polyploid, the former presumably decaploid and the latter more certainly tetraploid, their adaptive radiations involved no further change in chromosome number. The cytological uniformity within each group, while providing circumstantial evidence of monophyly and simplifying interpretations of cladistic analyses, provides neither positive nor negative support for a possible role of polyploidy in evolving the giant-rosette growth-form.
\end{abstract}

Since their discovery last century, the giant senecios (Dendrosenecio; Nordenstam, 1978) and giant lobelias (Lobelia subgenus Tupa section Rhynchopetalum; Mabberley, 1974b) of eastern Africa have attracted considerable attention from taxonomists and evolutionary biologists (cf. Bentham, 1873; Hoffmann, 1894; Fries and Fries, 1922a, b; Cotton, 1932, 1944; Bruce, 1934; Hauman, 1934, 1935; Humbert, 1935; Wimmer, 1953; Hedberg, 1957, 1969, 1973; Mabberley, 1973, 1974a, b, 1975; Nordenstam, 1977, 1978; Thulin, 1984, 1985; Jeffrey, 1986). They are premier examples of adaptive radiation because of the large number of morphological features and ecological syndromes that have evolved convergently in two families, the Asteraceae and the Lobeliaceae. One problem is the identification of each group's closest relatives and place of origin in eastern Africa. A second is the reconstruction of each group's evolutionary diversification. Mabberley (1973, 1974a, 1975), working within the framework of Corner's $(1949,1954)$ Durian Theory, considered the "pachycaul" (thick-stem) growth-form of these plants to be ancestral and the herbaceous growthform of their putative relatives to be derived. Most other workers (notably Carlquist, 1962, 1980) have interpreted the data as indicating an herbaceous ancestry with woodiness secondarily derived. Information on chromosome numbers, while giving only weak and partial evidence concerning origins and radiations, provides an essential aspect of the evolutionary history of any group and allows other data to be more intelligently interpreted.

\footnotetext{
' Received for publication 28 September 1992; revision accepted 13 January 1993.

The authors thank the Tanzanian Commission for Science and Technology, the Ugandan National Research Council, the Institute Zairois pour la Conservation de la Nature, the Office Rwandais du Tourisme et des Parcs Nationaux, and the Malawian General Secretary of the Association pour l'Étude Taxonomique de la Flore D'Afrique Tropical for permission to conduct research in their respective countries. This work was supported in part by NSF grants BSR-8800487 and BSR8901123 and awards from the Rackham School of Graduate Studies, University of Michigan.

2 Author for correspondence.
}

\section{MATERIALS AND METHODS}

Excised anthers or very young flower buds of Lobelia and immature heads of Dendrosenecio were fixed in the field in Carnoy's solution ( 3 chloroform : 2 absolute ethanol : 1 glacial acetic acid, v/v). After 1 or more days the material was transferred to $70 \%$ ethanol for storage at 4 C. Anthers were dissected from buds in $1 \%$ acetocarmine. The anthers of Lobelia are sufficiently large that, for most of the material, meiocytes were extruded from the transversely cut anther sacs. Debris was removed, and the material (intact anthers or meiocyte tissue) was placed in a fresh drop of $1 \%$ acetocarmine, heated slightly, and allowed to stain for 5 minutes. Intact anthers were washed three times with $45 \%$ acetic acid. A drop of Hoyer's mounting medium was added to the meiocyte tissue in $1 \%$ acetocarmine or to the intact anthers in $45 \%$ acetic acid, and the material was squashed (Beeks, 1955). Anthers giving counts had lengths of $0.8-1.7 \mathrm{~mm}$ for Dendrosenecio and 3-4 mm for Lobelia. Chromosome counts and photographs were made using a Zeiss phase-contrast microscope. Permanent slides are in the collection of the second author.

\section{RESULTS AND DISCUSSION}

The giant senecios and giant lobelias, although not closely related, are conceptually united by their convergent giant-rosette growth-form and their parallel adaptations to a variety of habitats in the mountains of eastern Africa. Parallels between the two groups also exist at the cytological level.

The giant senecios-Most species of giant senecio were discovered during the early colonial exploration of eastern Africa, starting with Senecio johnstonii in 1884 (Mabberley, 1973). Initially placed with other arborescent senecios in Senecio section Arborei O. Hoffmann (1894) and by itself in Muschler's (1909) redefined section Arborei, the taxon was later raised to subgeneric rank by Hauman (1935), a treatment formally validated by Hedberg (1957) 
as Dendrosenecio Hauman ex Hedberg. The giant senecios are inseparable from Senecio based on traditional characters of the heads and florets (Cotton, 1932, 1944; Hedberg, 1957; Mabberley, 1973, 1974a). However, using their habit, pyramidal-paniculate inflorescence, more-orless biseriate involucre, and continuous stigmatic surfaces of the disk styles in addition to minor differences in hairs and endothecial tissue, Nordenstam $(1977,1978)$ split the group from Senecio (as with many other groups) to form the genus Dendrosenecio (Hauman ex Hedberg) Nordenstam. Although initially unpersuaded (Jeffrey, 1979, 1986), Jeffrey (1992) now concurs in light of recent evidence (discussed below).

The large size of the giant senecios, while giving them a striking appearance in the field, often resulted in fragmentary and unrepresentative herbarium specimens (Knox, in press). This, along with the colonial subdivision of eastern Africa, contributed to an early proliferation of species descriptions. Hedberg's (1957) taxonomic revision significantly clarified the circumscription of taxa and the applications of the numerous names. Mabberley (1973) was interested in evolutionary reconstruction but found the "mosaic of variation" in the giant senecios difficult to interpret. He recognized two of the most distinctive species (one with two geographic subspecies) and submerged the rest as infraspecific taxa of a polymorphic Senecio (Dendrosenecio) johnstonil. Table 1 outlines a revised classification for Dendrosenecio (Knox, 1993).

The ancestral (base) chromosome number for Asteraceae tribe Senecioneae, as well as Senecio itself, is $x=10$ (Ornduff et al., 1967). Unconvincing arguments for $x=$ 5 (Turner and Lewis, 1965) are further vitiated because the $n=5$ "Senecio" species on which the arguments are based have been transferred to Emilia (Jeffrey, 1986). The two most recent sporophytic counts (Hedberg and Hedberg, 1977; Table 1), based on root tips from two species, and our 14 gametophytic counts (Table 1; Figs. 1-4), based on microspore mother cells representing six species (including the previous two) and eight infraspecific taxa, agree in giving $2 n=100$ and $n=5011$, respectively. The two earliest sporophytic counts of $2 n=\mathrm{ca}$. 80 (Thulin, 1970; Table 1) are, for now, best considered rough approximations for $2 n=100$, as did Hedberg and Hedberg (1977). The two sporophytic counts of $2 n=20$ for the two subspecies of Dendrosenecio cheranganiensis (Mabberley, 1971; Table 1) are wildly in disagreement but are best considered simply wrong. Their author's comment, "the chromosomes being large for the genus as a whole," may imply clumps of chromosomes, and our two counts from $D$. cheranganiensis spp. dalei clearly show $n=50 \mathrm{II}$.

Current evidence, from six of the 11 species and from all geographic areas except Mt. Kilimanjaro and Mt. Meru in Tanzania, identifies Dendrosenecio as uniformly decaploid with $n=50$. Despite the high chromosome number, meiosis is extremely regular (Figs. $1-3$ ), as in the Mexican Senecioneae (Barkley, 1985) with $n=30$ or 29 (e.g., two segregates of Cacalia, Odontotrichum and Psacalium, and three cacalioid segregates of Senecio, Pittocaulon, Roldana, and Telanthophora). This condition is unlike the polyploids of the temperate North American aureoid senecios $(x=23+22$; sometimes segregated as Packera) with $n=44,46$, and 69 and the South African Senecio serpens Rowley with $n=$ ca. 50 , where univalents and multivalents are common (Kowal, unpublished data). Meiotic regularity may be correlated with evolutionary age. The only irregularities seen are in one of the two individuals of $D$. cheranganiensis ssp. dalei, where some diakineses contain a univalent and/or one to three multivalents (Table 1; Fig. 4). The woodland ssp. cheranganiensis grows at the edge of the sedge meadows inhabited by ssp. dalei, and both flower at the same time, so hybridization is possible (Mabberley, 1971).

A gametophytic number of 50 is infrequent in the Senecioneae, occurring sporadically in the Australian ( $\mathrm{Ar}$ rhenechthites, Senecio), Ethiopian (Kleinia, Senecio), and Neotropical (Dendrophorbium, Graphistylis, Jacmaia, Pentacalia, Senecio, Werneria) biogeographical regions (Nordenstam, 1977; Jeffrey, 1979, 1992). However, so far it has not been helpful in pointing out a likely sister group for Dendrosenecio.

The radiation of the giant senecios may have been predicated on some genetic consequence of their high chromosome number, although this is not the case in the radiation of the convergent Espeletia (Asteraceae, Heliantheae) with $n=19$ (Powell and Cuatrecasas, 1975; Hunziker et al., 1989). Certainly the constant $n=50$ indicates that their speciation involved no changes in chromosome number.

Identification of the closest relatives of Dendrosenecio is necessary for understanding numerous evolutionary questions, including determining the ancestral chromosome number and the timing between the origins of the high number and the giant-rosette growth-form. Several species have been suggested: Senecio subsessilis Oliv. \& Hiern (Engler, 1892), a coarse herb of upland eastern Africa with $2 n=40$ (Hedberg and Hedberg, 1977), and other close allies in section Crociseris from Africa, such as $S$. ochrocarpus Oliv. \& Hiern and S. karaguensis $O$. Hoffm. (Mabberley, 1974a; Nordenstam, 1978); European species such as $S$. umbrosus Waldst. \& Kit. (Mabberley, 1974a) with $2 n=40$ (Zhukova, 1964; Hindakova, 1978 ) and $S$. doronicum L. (Mabberley, 1974a) with $2 n$ $=20,40$, and 60 (Kupfer, 1972); the South American $S$. hualtata DC. (Hauman, 1935); and the robust east African shrub, Solanecio gigas (Vatke) C. Jeffrey (Nordenstam, 1978). A study of restriction-site variation including all except $S$. hualtata, S. karaguensis, and $S$. umbrosus showed none to be close relatives to the giant senecios (Knox and Palmer, unpublished data). The phytochemistry is also quite distinctive between Dendrosenecio and Senecio (Bohlmann and Knox, unpublished data). Thus, the origin of the giant senecios is unresolved.

The giant lobelias - The greater morphological differentiation among the giant lobelias has resulted in more stable species delimitations than in Dendrosenecio and more discussion of evolutionary relationships. The large lobelias worldwide form Lobelia subgenus Tupa but with different sectional treatments (Bentham, 1873; Schönland, 1894; Wimmer, 1953). Mabberley (1974b) revised the east African members of section Rhynchopetalum to reflect his evolutionary interpretation (Mabberley, 1975), but his subsectional treatment needs revision due to recent evidence from chloroplast DNA (Knox, Downie, and Palmer, 1993; Knox and Palmer, unpublished data), the discovery of new species (Knox and Pócs, 1992; Knox, 


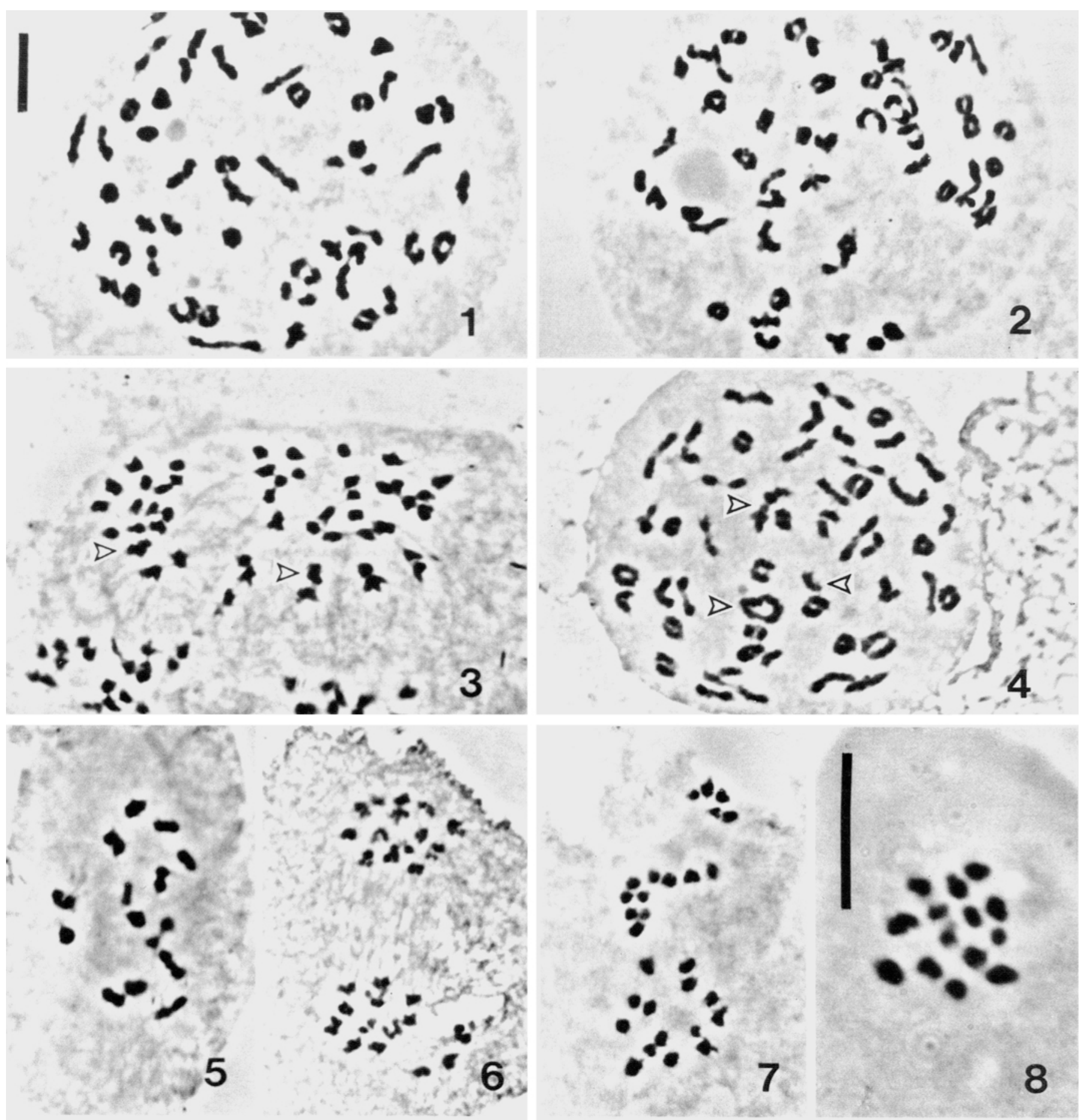

Figs. 1-8. Meiotic chromosomes of Dendrosenecio and Lobelia. Bar $=10 \mu \mathrm{m}$. 1. D. erici-rosenii $\mathrm{ssp}$. alticola, diakinesis, $n=50 \mathrm{II}(\mathrm{Knox} 383)$. 2. D. keniodendron, diakinesis, $n=50 \mathrm{II}$ (Knox 736). 3. D. erici-rosenii $\mathrm{ssp}$. alticola, anaphase I, $n=50$ (with arrowheads indicating two pairs of chromosomes; Knox 1820). 4. D. cheranganiensis ssp. dalei, diakinesis, $n=\mathrm{ca}$. $50(46 \mathrm{II}+2 \mathrm{II}+\mathrm{I}+\mathrm{III}$, with arrowheads indicating the three irregular figures; Knox 2102). 5. L. gregoriana ssp. gregoriana, metaphase I, $n=14 \mathrm{II}$ (Knox 757). 6. L. morogoroensis, metaphase II, $n=14$ (two plates shown; Knox 1045). 7. L. bequaertii, metaphase II, $n=14$ (two plates shown, with the small chromosome in the upper plate divided prematurely; Knox 215). 8. L. petiolata, metaphase II, $n=14$ (Knox 534).

1993, in press), and the clarification of several taxonomic problems. Table 2 lists the giant lobelias from eastern Africa (Knox, 1993).

The ancestral (base) chromosome number for Lobelia is $x=7$ (Lammers, 1992). The giant lobelias are all tetraploids with $2 n=28$ or ca. 28 and $n=14$ or ca. 14
(Table 2; Figs. 5-8). The sampling represents all but three of the 21 species and all major lineages revealed by chloroplast DNA (Knox and Palmer, unpublished data). None of the sporophytic (Table 2) or gametophytic material showed abnormalities, including $L$. bequaertii (Fig. 7), which is suspected of having an ancient hybrid origin 
TABLE 1. The giant senecios from eastern Africa with previously reported sporophytic and newly counted gametophytic chromosome numbers

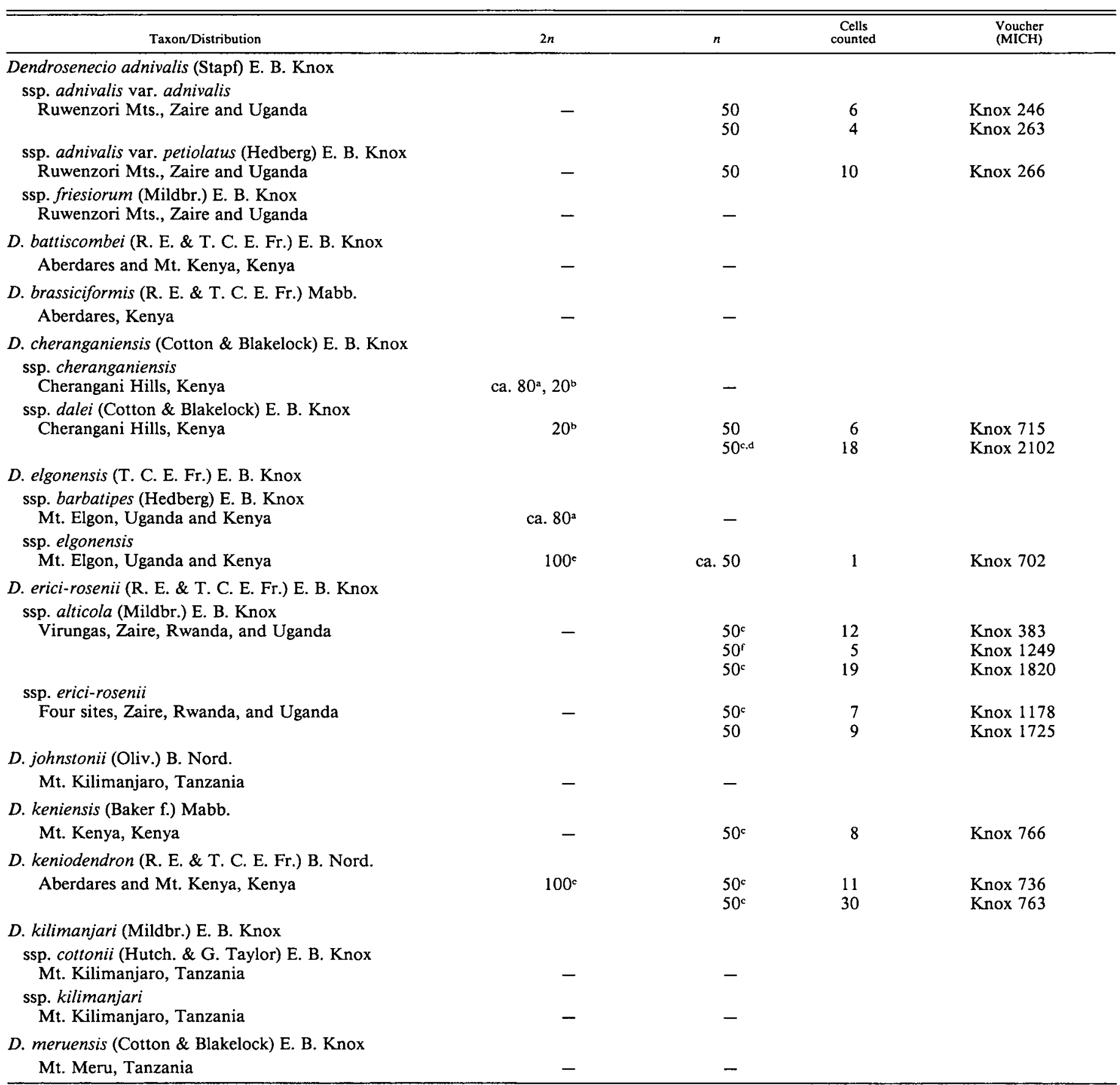

a Thulin (1970); considered a rough estimate for $2 n=100$.

b Mabberley (1971); considered to be wrong; see text.

c Documented by a photograph.

d Individual sometimes with one to three irregular bivalents such that six additional cells can be interpreted as a diploid number of 99 or 100 with equal likelihood and one additional cell is best interpreted as a diploid number of (48II +1 III $=) 99$.

' Hedberg and Hedberg (1977).

' Possibly with a fragment or B chromosome.

(Knox, unpublished data). Lobelia telekii may have one or two fragments, and L. wollastonii, whose count is based on sparse and lightly stained material, may have micronuclei, but otherwise meiosis is normal. In contrast, a field-collected hybrid between $L$. stuhlmannii and $L$. giberroa (grown from seed at the University of Michigan's
Matthaei Botanical Garden) showed meiotic irregularities such as univalents and trivalents. The plant's anthers were sterile and free (instead of connate), and many gynoecia were three-carpelate (instead of two-carpelate). In all of our meiotic material (Table 2; Figs. 5-8), one chromosome of the genome is more-or-less conspicuously small- 
TABLE 2. The giant lobelias from eastern Africa with previously reported sporophytic and newly counted gametophytic chromosome numbers

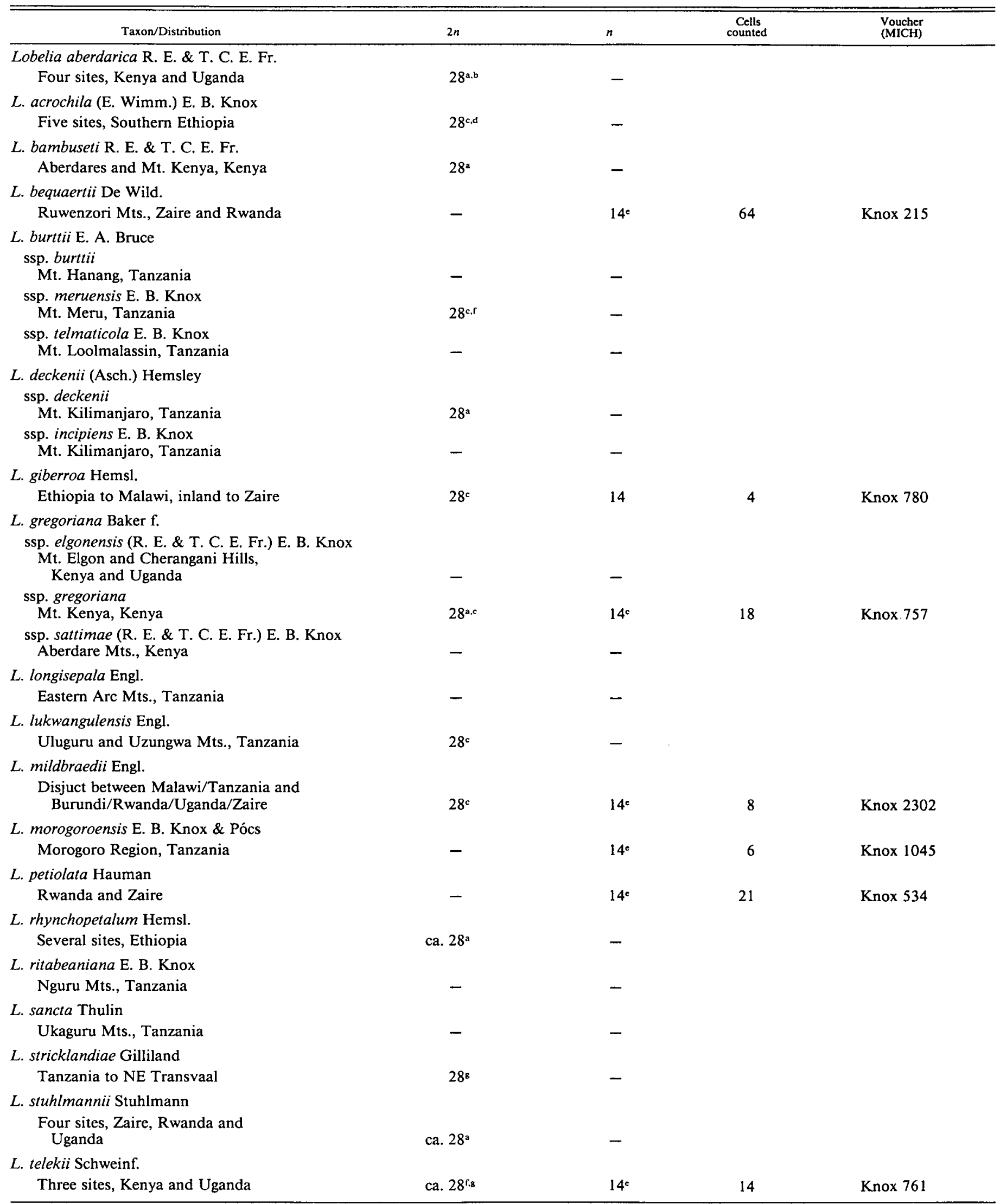


TABle 2. Continued

\begin{tabular}{|c|c|c|c|c|}
\hline Taxon/Distribution & $2 n$ & $n$ & $\begin{array}{c}\text { Cells } \\
\text { counted }\end{array}$ & $\begin{array}{l}\text { Voucher } \\
\text { (MICH) }\end{array}$ \\
\hline \multicolumn{5}{|l|}{ L. thuliniana E. B. Knox } \\
\hline Iringa Region, Tanzania & - & $14^{\mathrm{e}}$ & 11 & Knox 918 \\
\hline \multicolumn{5}{|l|}{ L. wollastonii Baker $\mathrm{f}$. } \\
\hline $\begin{array}{l}\text { Virunga and Ruwenzori Mts., } \\
\text { Zaire, Rwanda and Uganda }\end{array}$ & ca. $28^{f}$ & 14 & 3 & Knox 1247 \\
\hline $\begin{array}{l}\text { a Hedberg and Hedberg (1977). } \\
\text { b Thulin (1970). } \\
\text { c Thulin (1983). } \\
\text { d C. Puff (unpublished data). } \\
\text { ' Documented by a photograph. } \\
\text { ' Hedberg (1957). } \\
\text { ' Mabberley (1974b). }\end{array}$ & & & & \\
\hline
\end{tabular}

er. This could have arisen either by chromosomal differention after doubling or by an allopolyploid origin with one genome already having a smaller chromosome.

As with the giant senecios, the diversification of the giant lobelias in eastern Africa did not involve further polyploidy or other changes in chromosome number. Unlike the giant senecios, giant lobelias are found outside eastern Africa. The Asian Lobelia nicotianifolia (Kausik, 1938; Devar, 1981), the endemic $L$. boninensis (Ono and Masuda, 1981) from the Bonin Islands of Japan, and representatives of the Hawaiian section Revolutella (Skottsberg, 1955; Carr, 1978; Lammers, 1988) have $n=$ 14 and/or $2 n=28$. The basal phylogenetic position of these species from Asia and the Pacific relative to the giant lobelias from eastern Africa (Knox, Downie, and Palmer, 1993) indicates that the ancestor of the east African giant lobelias was already tetraploid, and that the diversification seen in eastern Africa is only one part of a larger pantropical radiation. As the search for the origin of the giant lobelias shifts back in time, the reports of $n$ $=7$ for the West Indian L. portoricensis (Nevling, 1966) and for the Peruvian L. decurrens (Diers, 1961) stand out as the only diploid counts within subgenus Tupa (in sections Tylomium and Homochilus, respectively). The one small chromosome in the genome may help identify ancestral lineages. The four Chilean species forming section Tupa are hexaploid with $2 n=42$ and $n=21$ (de Vilmorin and Simonet, 1927; Lammers and Hensold, 1992), and cladistically are segregated in a basal division of the giant lobelias worldwide (Knox, Downie, and Palmer, 1993).

Change in chromosome number has not been associated with evolution within the giant lobelias of eastern Africa; however, numerous changes have occurred in herbaceous lineages of Lobeliaceae, including those represented in the molecular systematic study of Knox, Downie, and Palmer (1993). Lobelia holstii and $L$. fervens both have $2 n=12$ (Thulin, 1983), wild populations of $L$. erinus have $2 n=$ 14 or 28 (Thulin, 1983) with cultivars showing $2 n=28$ or 42 (de Vilmorin and Simonet, 1927), and L. cardinalis has $2 n=14$ (e.g., de Vilmorin and Simonet, 1927; Bowden, 1958). No count is available for Monopsis lutea, but a related species, $M$. stellarioides, has $2 n=28$ (Hedberg and Hedberg, 1977). Chloroplast DNA rearrangements and restriction-site variation (Knox, Downie, and Palmer,
1993) both indicate a pattern of relationship in which the core lineage of Lobelia is diploid, and these polyploid increases in chromosome number (with some aneuploid decreases) have been independently derived. For example, $L$. fervens and $L$. erinus are closely related, sharing a distinctively rearranged chloroplast genome and being morphologically similar (Thulin, 1984). Aneuploidy and polyploidy have both occurred within this small clade.

The adaptive radiations of the giant senecios and giant lobelias in eastern Africa have occurred with no change in chromosome numbers. This knowledge limits the number of possible evolutionary scenarios and simplifies the interpretation of other phylogenetic data. Polyploidy may have been a necessary precondition for adaptation to tropical montane habitats and evolution of the giant-rosette growth-form, but support for such a claim requires much additional information, such as the identity of the closest diploid relatives, and information from many additional fields, such as physiological ecology.

\section{LITERATURE CITED}

BARKLEY, T. M. 1985. Infrageneric groups in Senecio, s.l., and Cacalia, s.l. (Asteraceae: Senecioneae) in Mexico and Central America. Brittonia 37: 211-218.

BEEks, R. M. 1955. Improvement in the squash technique for plant chromosomes. Aliso 3: 131-133.

Bentham, G. 1873. Campanulaceae. In G. Bentham and J. D. Hooker [eds.], Genera Plantarum, vol. 2, 541-564. Reeve and Co., London.

BOWDEN, W. M. 1958. Phylogeny of twenty-one species of Lobelia L. section Lobelia. Bulletin of the Torrey Botanical Club 86: 94-108.

BRUCE, E. A. 1934. The giant lobelias of East Africa. Bulletin of Mis. cellaneous Information 1934: 61-88, 274.

CARLQuist, S. 1962. A theory of paedomorphosis in dicotyledonous woods. Phytomorphology 12: 30-45.

- 1980. Further concepts in ecological wood anatomy, with comments on recent work in wood anatomy and evolution. Aliso 9: 499-553.

CARR, G. D. 1978. Chromosome numbers of Hawaiian flowering plants and the significance of cytology in selected taxa. American Journal of Botany 65: 236-242.

CORNER, E. J. H. 1949. The Durian Theory or the origin of the modern tree. Annals of Botany (London) 13: 367-414 (New series).

- 1954. The Durian Theory extended-III. Pachycauly and megaspermy-conclusion. Phytomorphology 4: 263-274.

Cotton, A. D. 1932. The tree senecios of the African mountains. 
Proceedings of the Linnean Society of London 1931-1932: 110111.

- 1944. The megaphytic habit in the tree senecios and other genera. Proceedings of the Linnean Society of London, Session 156: $158-168$.

Devar, K. V. 1981. Chromosome number reports LXXI. Taxon 30: 506.

DE VILMORIN, R., AND M. Simonet. 1927. Nombre des chromosomes dans les genres Lobelia, Linum et chez quelques autre espèces végétales. Comptes-Rendus Hebdomadaires des Séances at Mémoires de la Société de Biologie, Paris 96: 166-168.

Diers, L. 1961. Der anteil an polyploiden in den vegetationsgürteln der west kordillere perus. Zeitschrift für Botanik 49: 437-488.

ENGLER, A. 1892. Über die Hochgebirgsflora des tropischen Afrika. Abhandlungen der Königlichen Akademie der Wissenschaften zu Berlin 1891: 1-461.

Fries, R. E., AND T. C. E. Fries. 1922a. Über die Riesen-Senecionen der afrikanischen Hochgebirge. Svensk Botanisk Tidskrift 16: 321340.

$\longrightarrow$, AND — 1922b. Die Riesen-Lobelien Afrikas. Svensk Botanisk Tidskrift 16: 383-416.

Hauman, L. 1934. Les Lobelia géants des montagnes du Congo Belge. Mémoires de l'Institute Royal Colonial Belge; Section des Sciences Naturelles et Médicales (80) 2: 1-52.

- 1935. Les Senecio arborescents du Congo. Revue de Zoologie et de Botanique Africaines 28: 1-76.

Hedberg, I., AND O. Hedberg. 1977. Chromosome numbers of afroalpine and afromontane angiosperms. Botaniska Notiser 130: 124.

HEDBERG, O. 1957. Afroalpine vascular plants: a taxonomic revision. Symbolae Botanicae Upsaliensis 15: 1-411.

- 1969. Evolution and speciation in a tropical high mountain flora. Biological Journal of the Linnean Society 1: 135-148.

- 1973. Adaptive evolution in a tropical-alpine environment. In V. H. Heywood [ed.], Taxonomy and ecology, Systematics Association Special vol. 5, 71-92. Academic Press, London.

HiNDAKOVA, M. 1978. In Index of chromosome numbers of Slovakian flora. Part 6. Acta Facultatis Rerum Naturalium Universitatis Comenianae, Botanica 26: 1-42.

HoffManN, O. 1894. Compositae. In A. Engler and K. Prantl [eds.], Die Natürlichen Pflanzenfamilien, IV(5), 87-387. Engelmann, Leipzig.

Humbert, H. 1935. Sur un Senecio arborescent nouveau des hautes montagnes du Congo belge et sur les liens phylogénétiques des espèces alliées. Bulletin de la Société Botanique de France 81 : 830 848.

Hunziker, J. H., A. WulfF, C. C. Xifreda, ANd A. Escobar. 1989. Estudios cariológicos en Compositae V. Darwiniana 29: 25-39.

JEFFREY, C. 1979. Generic and sectional limits in Senecio (Compositae): II. Evaluation of some recent studies. Kew Bulletin 34: 4958.

- 1986. The Senecioneae in east tropical Africa. Notes on Compositae: IV. Kew Bulletin 41: 873-943.

- 1992. The tribe Senecioneae (Compositae) in the Mascarene Islands with an annotated world check-list of the genera in the tribe. Notes on Compositae: VI. Kew Bulletin 47: 49-109.

KAUSIK, S. B. 1938. Gametogenesis and embryology in Lobelia nicotianaefolia Heyne. Journal of the Indian Botanical Society 17: 161168.

KNox, E. B. In press. Species concepts in the giant lobelias and giant senecios. Proceedings of the XIIIth A.E.T.F.A.T. Congress, Zomba, Malawi.

1993. The species of giant senecio (Compositae) and giant lobelia (Lobeliaceae) in eastern Africa. Contributions from the University of Michigan Herbarium 19: 241-257.

$\longrightarrow$, S. R. DownIE, AND J. D. PALMer. 1993. Chloroplast genome rearrangements and the evolution of giant lobelias from herbaceous ancestors. Molecular Biology and Evolution 10: 414-430.
- - AND T. Pócs. 1992. Lobelia morogoroensis: another Tanzanian giant. Kew Bulletin 47: 503-508.

KuPFER, M. P. 1972. Cytotaxonomie et cytogéographie de quelques groupes d'orophytes du bassin occidental de la mediterranée et des Alpes. Comptes Rendus Hebdomadaires des Séances de l'Académie des Sciences, Series D 275: 1753-1756.

LAmmers, T. G. 1988. Chromosome numbers and their systematic implications in Hawaiian Lobelioideae (Campanulaceae). American Journal of Botany 75: 1130-1134.

- 1992. Circumscription and phylogeny of the Campanaulales. Annals of the Missouri Botanical Garden 79: 388-413.

- AND N. HeNsold. 1992. Chromosome numbers of Lobelioideae (Campanulaceae). II. The Lobelia tupa complex of Chile. American Journal of Botany 79: 585-588.

MabBerLeY, D. J. 1971. The dendrosenecios of the Cherangani Hills. Kew Bulletin 26: 33-36.

. 1973. Evolution of the giant groundsels. Kew Bulletin 28: 6196

- 1974a. Branching in pachycaul senecios: the Durian Theory and the evolution of angiospermous trees and herbs. New Phytologist 73: $967-975$.

- 1974b. The pachycaul lobelias of Africa and St. Helena. Kew Bulletin 29: 535-584.

- 1975. The giant lobelias: pachycauly, biogeography, ornithophily and continental drift. New Phytologist 74: 365-374.

MusChler, R. 1909. Systematische und Pflanzengeographische Gliederung der Afrikanischen Senecio-Arten. Botanische Jahrbücher für Systematik, Pflanzengeshichte und Pflanzengeographie 43: 1-74.

Nevling, L. I. 1966. IOPB chromosome number reports VI. Taxon 15: $117-128$

NordenStAm, B. 1977. Senecioneae and Liabeae-systematic review. In V. H. Heywood, J. B. Harborne, and B. L. Turner [eds.], The biology and chemistry of the Compositae, 799-830. Academic Press, New York, NY.

- 1978. Taxonomic studies in the tribe Senecioneae (Compositae). Opera Botanica 44: 1-84.

ONo, M., AND Y. Masuda. 1981. Chromosome numbers of some endemic species of the Bonin Islands II. Ogasawara Research 4: 124.

Ornduff, R., T. Mosquin, D. W. Kyhos, AND P. H. RaVen. 1967. Chromosome numbers in Compositae. VI. Senecioneae. American Journal of Botany 54: 205-213.

Powell, A. M., AND J. Cuatrecasas. 1975. IOPB chromosome number reports L. Taxon 24: 671-678.

SChönland, S. 1894. Campanulaceae. In A. Engler and K. Prantl [eds.], Die Natürlichen Pflanzenfamilien, IV(5), 40-70. Engelmann, Leipzig.

SkotTSBERG, C. 1955. Chromosome numbers in Hawaiian flowering plants. Arkiv für Botanik 3: 63-70.

ThuLIN, M. 1970. Chromosome numbers of some vascular plants from East Africa. Botaniska Notiser 123: 488-494.

- 1983. Some tropical African Lobeliaceae. Chromosome numbers, new taxa and comments on taxonomy and nomenclature. Nordic Journal of Botany 3: 371-382.

. 1984. Lobeliaceae [fasc., 59 pp.]. In R. M. Polhill [ed.], Flora of Tropical East Africa. A. A. Balkema, Rotterdam.

. 1985. Lobeliaceae [fasc., 65 pp.]. In P. Bamps [ed.], Flore d'Afrique Centrale (Zaire-Rwanda-Burundi). Jardin botanique national de Belgique, Meise.

Turner, B. L., AND W. H. LewIS. 1965. Chromosome numbers in the Compositae. IX. African species. Journal of South African Botany 31: 207-217.

Wimmer, F. E. 1953. Campanulaceae-Lobelioideae. Teil II. In R. Mansfeld [ed.], Das Pflanzenreich IV, 267b (107 Heft). Akademie Verlag, Berlin.

Zhukova, P. G. 1964. The caryology of some species of Compositae growing in the Arcto-Alpine Botanic Garden (Kola Peninsula). Botanicheskii Zhurnal, Moscow \& Leningrad 49: 1656-1659. 